Article

\title{
Antimicrobial, Antioxidant, and Anticancer Activities of Biosynthesized Silver Nanoparticles Using Marine Algae Ecklonia cava
}

\author{
Jayachandran Venkatesan ${ }^{1}$, Se-Kwon Kim ${ }^{2}$ and Min Suk Shim ${ }^{1, *}$ \\ 1 Division of Bioengineering, Incheon National University, Incheon 406-772, Korea; venkatjchem@gmail.com \\ 2 Marine Bioprocess Research Center, Pukyong National University, Busan 608-737, Korea; \\ sknkim@pknu.ac.kr \\ * Correspondence: msshim@inu.ac.kr; Tel.: +82-32-835-8268
}

Academic Editor: Guogang Ren

Received: 14 September 2016; Accepted: 25 November 2016; Published: 6 December 2016

\begin{abstract}
Green synthesis of silver nanoparticles (AgNPs) has gained great interest as a simple and eco-friendly alternative to conventional chemical methods. In this study, AgNPs were synthesized by using extracts of marine algae Ecklonia cava as reducing and capping agents. The formation of AgNPs using aqueous extract of Ecklonia cava was confirmed visually by color change and their surface plasmon resonance peak at $418 \mathrm{~nm}$, measured by UV-visible spectroscopy. The size, shape, and morphology of the biosynthesized AgNPs were observed by transmission electron microscopy and dynamic light scattering analysis. The biosynthesized AgNPs were nearly spherical in shape with an average size around $43 \mathrm{~nm}$. Fourier transform-infrared spectroscopy (FTIR) analysis confirmed the presence of phenolic compounds in the aqueous extract of Ecklonia cava as reducing and capping agents. X-ray diffraction (XRD) analysis was also carried out to demonstrate the crystalline nature of the biosynthesized AgNPs. Antimicrobial results determined by an agar well diffusion assay demonstrated a significant antibacterial activity of the AgNPs against Escherichia coli and Staphylococcus aureus. Antioxidant results determined by 1,1-diphenyl-2-picrylhydrazyl (DPPH) scavenging assay revealed an efficient antioxidant activity of the biosynthesized AgNPs. The biosynthesized AgNPs also exhibited a strong apoptotic anticancer activity against human cervical cancer cells. Our findings demonstrate that aqueous extract of Ecklonia cava is an effective reducing agent for green synthesis of AgNPs with efficient antimicrobial, antioxidant, and anticancer activities.
\end{abstract}

Keywords: anticancer; antimicrobial; antioxidant; biosynthesis; Ecklonia cava; nanoparticle

\section{Introduction}

In recent years, noble metal nanoparticles (NPs) have been intensively utilized for biomedical applications, such as diagnostics, drug delivery, and tissue engineering, due to their unique physicochemical and optoelectronic properties [1-4]. Among various noble metal nanoparticles, silver nanoparticles (AgNPs) have received great attention in a variety of applications, including nanoelectronic devices, sensors, imaging contrast agents, filters, and antimicrobial agents due to their good electrical conductivity, stability, optical property, and antimicrobial activity [5,6]. AgNPs have also extended their applications to cancer therapy. Several in vitro studies using AgNPs have demonstrated their potential as effective anticancer agents [7-10]. They have exhibited apoptosis-mediated, strong anticancer efficacies in a variety of cancer cells, including human cervical cancer [8], lung cancer [9], and breast cancer cells [10].

It has been well-documented that performance and applicability of AgNPs critically depend on their size, shape, composition, and surface chemistry [11-13]. Synthesis of noble 
metal NPs with controlled shape and size can be achieved through many different synthetic methods: evaporation-condensation, gamma irradiation, electron irradiation, microwave processing, microemulsion, sonochemical, electrochemical, photochemical, etc. [14-17]. One of the popular methods for the synthesis of defined noble metal NPs is chemical reduction [14]. Reduction of silver complexes in dilute solution with a proper reductant can lead to the formation of colloidal AgNPs [14]. Although this method offers significant advantages of simple equipment and convenient operation, it involves a use of hazardous chemicals and high temperature conditions, which are rather environmentally unfriendly and energetically inefficient $[14,18]$.

To overcome the drawbacks of the chemical reduction method, biogenic synthesis that employs microorganisms and naturally occurring products has emerged as an environmentally friendly synthetic method (i.e., green chemistry) [17,19-21]. This method offers a facile and convenient entry to producing various noble metal NPs. Biogenic synthesis of noble metal NPs mainly relies on various extracts (e.g., nucleic acids, enzymes, proteins, peptides, vitamins, and polysaccharides) of microorganisms. For example, extracts of fungi, bacteria, and algae were extensively utilized to synthesize AgNPs, as shown in Table 1.

Table 1. Biosynthesized AgNPs using various microorganisms.

\begin{tabular}{|c|c|c|c|c|c|}
\hline No. & Species & Reaction Time & Size & Applications & Ref. \\
\hline 2 & Chaetoceros calcitrans & 2 weeks & N.A. & Antimicrobial & [22] \\
\hline 4 & Porphyra vietnamensis & $15 \mathrm{~min}$ & $13 \pm 3 \mathrm{~nm}$ & Antibacterial & [24] \\
\hline 5 & Gelidiella acerosa & $48 \mathrm{~h}$ & $22 \mathrm{~nm}$ & Antifungal & {$[25]$} \\
\hline 6 & Sargassum tenerrimum & $20 \mathrm{~min}$ & $20 \mathrm{~nm}$ & Anti-bacterial & [26] \\
\hline 9 & Turbinaria conoides & N.A & $96 \mathrm{~nm}$ & Antibacterial & [29] \\
\hline 10 & Padina pavonica & $24 \mathrm{~h}$ & $46.8 \mathrm{~nm}$ & Antimicrobial & [30] \\
\hline 11 & Cryphonectria & $24 \mathrm{~h}$ & $30-70 \mathrm{~nm}$ & Antimicrobial & [31] \\
\hline 12 & $\begin{array}{l}\text { Pterocladia capillacae, Jania rubins, } \\
\text { Ulva faciata, Colpmenia sinusa }\end{array}$ & $3 \mathrm{~h}$ & $20 \mathrm{~nm}$ & Antimicrobial & [32] \\
\hline 17 & Sargassum longifolium & $64 \mathrm{~h}$ & N.A. & Antifungal & [37] \\
\hline 18 & Pithophora oedogonia & N.A. & $34.03 \mathrm{~nm}$ & Antibacterial & [38] \\
\hline 19 & Sesbania grandiflora & $15 \mathrm{~min}$ & $12 \mathrm{~nm}$ & Antimicrobial & [39] \\
\hline 20 & Stenotrophomonas maltophilia & N.A. & $93 \mathrm{~nm}$ & Antimicrobial & {$[40]$} \\
\hline 21 & Croton bonplandianum & N.A. & $32 \mathrm{~nm}$ & Antimicrobial and anticancer & [41] \\
\hline 22 & Chenopodium murale & N.A. & $30-50 \mathrm{~nm}$ & Antimicrobial & {$[42]$} \\
\hline 23 & Alternanthera sessilis & N.A. & $10-30 \mathrm{~nm}$ & Anticancer & [43] \\
\hline 24 & Pseudomonas putida & $20 \mathrm{~min}$ & $6-16 \mathrm{~nm}$ & Antibacterial and anticancer & [44] \\
\hline 25 & Citrullus colocynthis & $24 \mathrm{~h}$ & $31 \mathrm{~nm}$ & Anticancer & {$[45]$} \\
\hline 26 & Chlorella vulgaris & $24 \mathrm{~h}$ & $7 \mathrm{~nm}$ & Anticancer and antimicrobial & [46] \\
\hline 27 & Lovoa trichilioïdes & $2 \mathrm{~h}$ & $37-43 \mathrm{~nm}$ & Anti-bacterial & [47] \\
\hline 35 & Spirogyra varians & N.A. & $17.6 \mathrm{~nm}$ & Antibacterial & [55] \\
\hline 36 & Enteromorpha flexuos & N.A. & $2-32 \mathrm{~nm}$ & Antimicrobial & [56] \\
\hline 37 & Cyanobacteria and Microalgae & $72 \mathrm{~h}$ & $13-31 \mathrm{~nm}$ & Antibacterial & [57] \\
\hline 38 & Dracocephalum moldavica & $1 \mathrm{~h}$ & $31 \pm 6 \mathrm{~nm}$ & Antimicrobial & [58] \\
\hline 39 & Dimocarpus longan Lour. & $5 \mathrm{~h}$ & $9-32 \mathrm{~nm}$ & Anticancer & [59] \\
\hline 40 & Curculigo orchioides rhizome & N.A. & $15-18 \mathrm{~nm}$ & Larvicidal and Anticancer & {$[60]$} \\
\hline 41 & Rhus chinensis & $12 \mathrm{~h}$ & $150 \mathrm{~nm}$. & Antibacterial & [61] \\
\hline
\end{tabular}


Seaweeds from the ocean are considered as "sea vegetables", commonly used as food in Asia-Pacific areas such as Korea, China, and Japan. Seaweeds are often used to produce hydrocolloids such as alginate, agar, and carrageenan. Ecklonia cava is an edible brown alga, mainly present in Korea, Japan, and China. Previous studies reported that phlorotannins such as phloroglucinol are main components in Ecklonia cava [62-65]. These compounds in Ecklonia cava have proved to be responsible for bioactivities such as antioxidant [62,66], anticancer [67-69], and antimicrobial activities [70]. In addition, antioxidant compounds from Ecklonia cava extracts, including (a) phloroglucinol; (b) eckol; (c) fucodiphlorethol G; (d) phlorofucofuroeckol A; (e) 7-phloroeckol; (f) dieckol; (g) 6,6'-bieckol; (h) triphlorethol-A; and (i) 2,7'-phloroglucinol-6,6'-bieckol (Figure 1) [42,62,67-71], could act as effective reductants to synthesize noble metal NPs.<smiles>Oc1cc(O)cc(O)c1</smiles>

b<smiles>OC1=CC(O)C(Oc2cc(O)cc3c2Oc2c(Oc4cc(O)cc(O)c4)c(O)cc(O)c2O3)C(O)=C1</smiles><smiles>C=C(C)Oc1c(O)cc(O)c2c1Oc1c(O)cc(O)cc1O2</smiles>

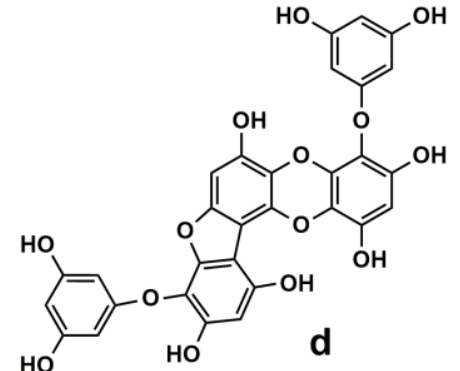

C<smiles></smiles><smiles>Oc1cc(O)cc(Oc2c(O)cc(O)cc2Oc2c(O)cc(O)cc2O)c1</smiles><smiles></smiles>

Figure 1. Chemical structures of:

(a) phloroglucinol; (b) eckol; (c) fucodiphlorethol G; (d) phlorofucofuroeckol A; (e) 7-phloroeckol; (f) dieckol; (g) 6,6'-bieckol; (h) triphlorethol-A; and (i) 2,7'-phloroglucinol-6,6'-bieckol.

In this study, AgNPs were synthesized via reduction of silver ions using aqueous extracts of Ecklonia cava as an alternative to conventional chemical reduction methods. To the best of our 
knowledge, use of Ecklonia cava extracts for the biosynthesis of AgNPs has not been attempted yet. We synthesize AgNPs and subsequently characterize their morphologies and compositions. We also investigate whether phloroglucinol and their derivatives obtained from Ecklonia cava contribute to the reduction of silver ions required for the formation of AgNPs. Antimicrobial, antioxidant, and anticancer activities of the biosynthesized AgNPs are also investigated.

\section{Results and Discussion}

\subsection{Biosynthesis of AgNPs and Characterization by UV-Vis Spectroscopy}

Aqueous extract of Ecklonia cava $(1 \% w / w)$ was mixed with $1 \mathrm{mM}$ of silver nitrate $\left(\mathrm{AgNO}_{3}\right)$ solution at room temperature. The formation of AgNPs was confirmed by the appearance of dark yellow color, which is a typical color of AgNPs in solution due to their surface plasmon resonance (SPR) [72]. The color of reaction solution was yellowish brown upon $1 \mathrm{~h}$ of reaction, but it changed to dark brown color when full reduction of silver ions was completed at $72 \mathrm{~h}$ (Figure 2).

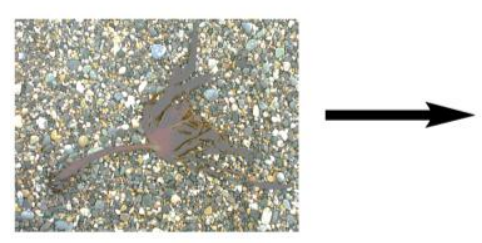

Ecklonia cava

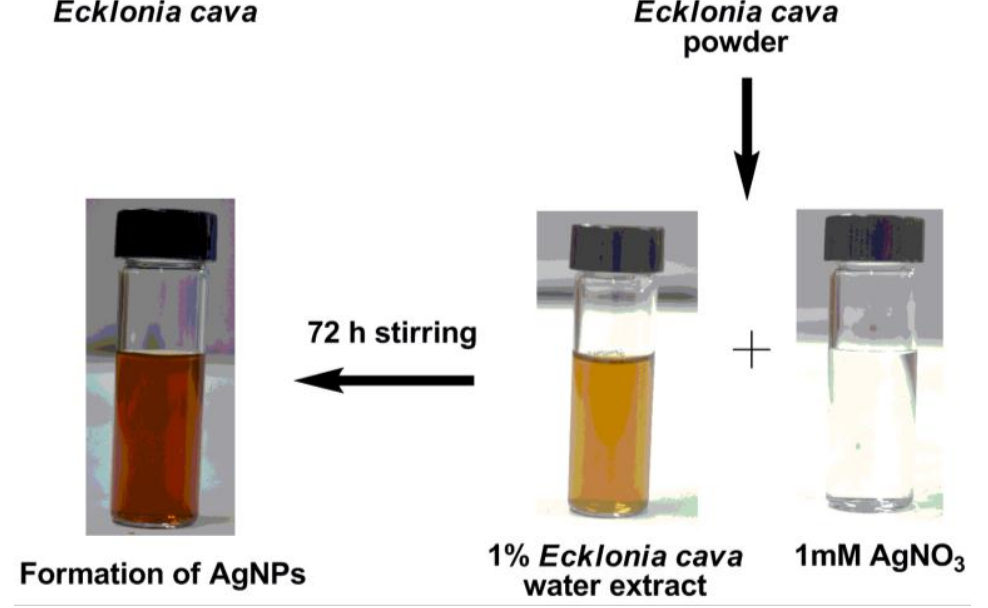

Figure 2. Schematic representation of green synthesis of AgNPs. Ecklonia cava is collected from the sea and then ground into a fine powder. The aqueous extract of Ecklonia cava is mixed with $1 \mathrm{mM} \mathrm{AgNO}_{3}$ solution and stirred for $72 \mathrm{~h}$ to synthesize AgNPs.

UV-Vis spectroscopy was used to confirm the synthesis of AgNPs with aqueous extract of Ecklonia cava. UV-Vis spectra scanned after time intervals of $0.5 \mathrm{~h}, 1 \mathrm{~h}, 18 \mathrm{~h}$, and $24 \mathrm{~h}$ from the initiation of reaction are represented in Figure 3. Strong SPR peak of AgNPs at $418 \mathrm{~nm}$ was clearly observed upon $18 \mathrm{~h}$ of reaction, indicating the formation of AgNPs. It was also found that intensity of the SPR peak increased with reaction time (Figure 3), demonstrating the increased concentration of AgNPs. The UV-Vis spectra and visual observation demonstrate that formation of AgNPs was almost completed within $24 \mathrm{~h}$. We also investigated the effect of temperature on the formation of AgNPs. When the reaction temperature increased to $200^{\circ} \mathrm{C}$, the formation of AgNPs was accelerated and thus completed within $5 \mathrm{~h}$ (data not shown). 


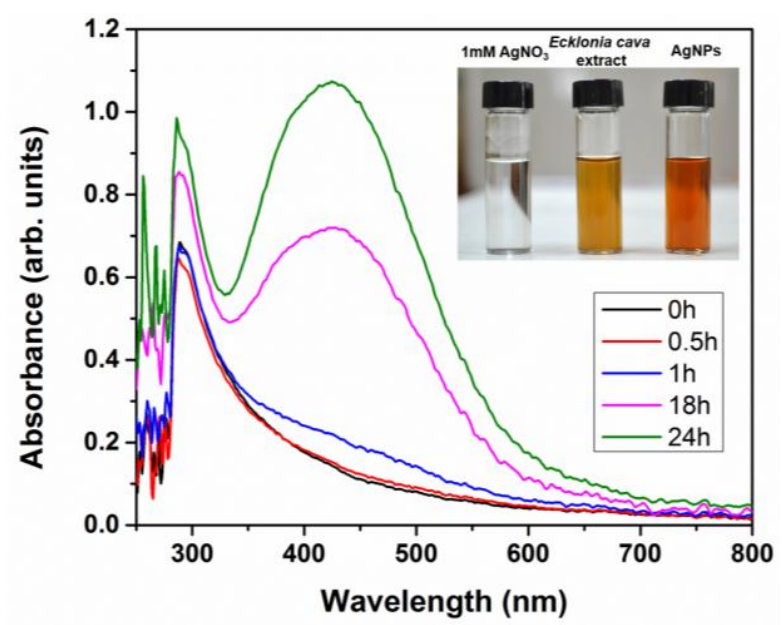

Figure 3. UV-Vis absorption spectra of biosynthesized AgNPs at different time intervals.

\subsection{Thermogravimetric Analysis (TGA)}

Thermal properties of Ecklonia cava extracts and biosynthesized AgNPs were confirmed by thermogravimetric analysis (TGA) using a Pyris 1 TGA analyzer (Perkin-Elmer, Waltham, MA, USA), as shown in Figure 4. The TGA result exhibits the strong deflection point at $230{ }^{\circ} \mathrm{C}$ for Ecklonia cava extracts, indicating their decomposition temperature. No significant difference has been observed in TGA curves between Ecklonia cava extracts and AgNPs. This result clearly indicates the presence of organic materials (i.e., Ecklonia cava) in the biosynthesized AgNPs.

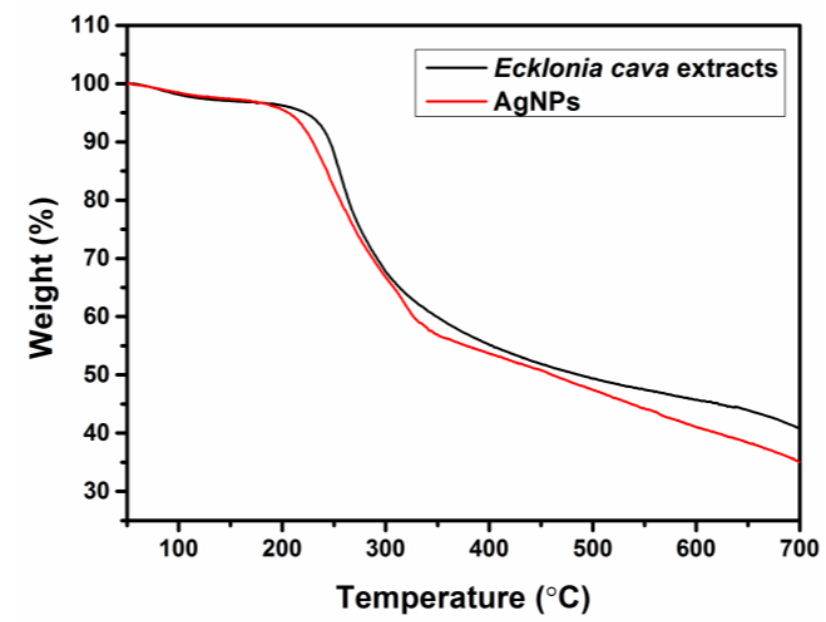

Figure 4. Thermogravimetric analysis of aqueous extract of Ecklonia cava (black curve) and biosynthesized AgNPs (red curve).

\subsection{Fourier Transform-Infrared (FT-IR) Spectroscopy}

To determine the possible biomolecules and functional groups involved in the formation of AgNPs, FT-IR spectroscopy was employed. FT-IR spectra of biosynthesized AgNPs and aqueous extract of Ecklonia cava were shown in Figure 5. The aqueous extract of Ecklonia cava showed the peaks at $871 \mathrm{~cm}^{-1}, 1027 \mathrm{~cm}^{-1}, 1231 \mathrm{~cm}^{-1}, 1412 \mathrm{~cm}^{-1}, 1600 \mathrm{~cm}^{-1}$, and $3341 \mathrm{~cm}^{-1}$. The broad peak around $3341 \mathrm{~cm}^{-1}$ in the spectra indicates the existence of $\mathrm{O}-\mathrm{H}$ group of polyphenols or polysaccharides. The absorption band observed at $1600 \mathrm{~cm}^{-1}$ can be assigned to the $\mathrm{N}-\mathrm{H}$ bending vibration of amine or amide groups [32]. The band observed at $1412 \mathrm{~cm}^{-1}$ is attributed to the $\mathrm{C}-\mathrm{N}$ stretching vibration of amine or amide groups [73]. The absorption bands at $1231 \mathrm{~cm}^{-1}$ and $1027 \mathrm{~cm}^{-1}$ correspond to $\mathrm{C}-\mathrm{O}$ 
or C-O-C stretching vibrations [74]. Similar kinds of peaks were observed at $823 \mathrm{~cm}^{-1}, 1030 \mathrm{~cm}^{-1}$, $1243 \mathrm{~cm}^{-1}, 1370 \mathrm{~cm}^{-1}, 1609 \mathrm{~cm}^{-1}$, and $3347 \mathrm{~cm}^{-1}$ for biosynthesized AgNPs (Figure 5A). Similar FT-IR absorption bands from the AgNPs implies that aqueous extract of Ecklonia cava could act as capping agents as well as reducing agents for the formation of stable AgNPs.

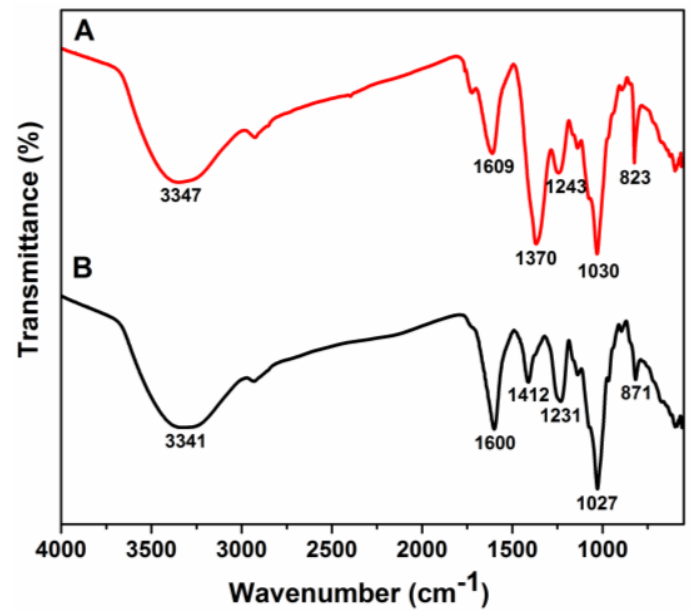

Figure 5. Fourier transform-infrared spectra of: (A) biosynthesized AgNPs; and (B) aqueous extract of Ecklonia cava.

\subsection{X-ray Diffraction (XRD) Analysis}

An XRD spectrum of biosynthesized AgNPs is shown in Figure 6. Distinct XRD patterns were observed at $28.0^{\circ}, 32.5^{\circ}, 38.2^{\circ}, 44.3^{\circ}, 46.4^{\circ}, 55.1^{\circ}, 57.5^{\circ}, 64.6^{\circ}$, and 77. $2^{\circ}$. The peaks at $2 \theta$ values of $38.2^{\circ}$, $44.3^{\circ}, 64.6^{\circ}$ and $77.2^{\circ}$ corresponds to $\left(\begin{array}{lll}1 & 1 & 1\end{array}\right),(200),(220)$, and (3 11 ) planes of face-centered cubic (FCC) structure of silver, respectively (Joint Committee on Powder Diffraction Standard (JCPDS) file: 04-0783). It is in agreement with several studies that have reported similar XRD patterns of biosynthesized AgNPs [59]. It was found that other co-existing peaks at $2 \theta$ values of $28.0^{\circ}, 32.5^{\circ}, 46.4^{\circ}, 55.1^{\circ}$, and $57.5^{\circ}$ correspond to (1 11 1), (2 00 0), (2 200$),\left(\begin{array}{lll}3 & 1 & 1\end{array}\right)$, and (2 22 2) planes of face-centered cubic crystalline phase of silver chloride, respectively (JCPDS file: 31-1238) [75-80]. This result clearly indicates the production of $\mathrm{Ag} / \mathrm{AgCl}$ composite nanoparticles (Ag/AgCl NPs) using aqueous extract of Ecklonia cava. The chloride ions might be originated from aqueous extract of Ecklonia cava. The formation of AgCl NPs might be attributed to the interaction of silver ions with chloride ions present in aqueous extract of Ecklonia cava. Similar results have been previously reported regarding the biosynthesis of AgNPs [75,78].

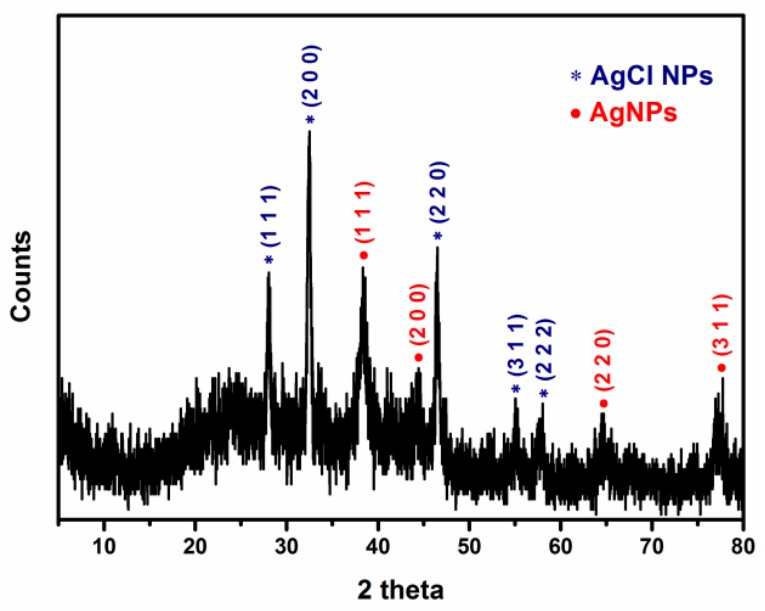

Figure 6. X-ray diffraction patterns of biosynthesized AgNPs (dot circle) and AgCl NPs (asterisk). 


\subsection{Size and Morphology Analysis of Biosynthesized AgNPs}

Transmission electron microscopy (TEM) images of biosynthesized AgNPs in different magnifications were shown in Figure 7. The AgNPs were polydispersed, and their sizes were in the range of 15-30 nm (Figure 7A,B). In addition, most of them were of spherical shape. The mean hydrodynamic diameter of the AgNPs dispersed in deionized water, determined by DLS, was $43 \mathrm{~nm}$ with PDI of 0.27 (Figure 7C).

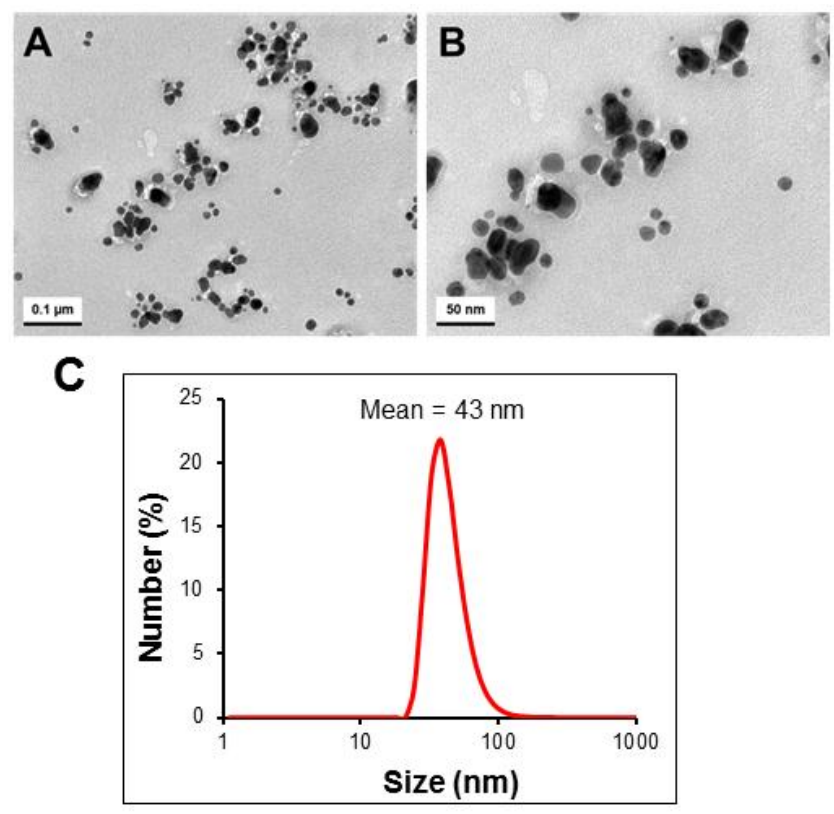

Figure 7. (A,B) Transmission electron microscopy images of biosynthesized AgNPs at different magnifications; and $(C)$ particle size distribution of AgNPs determined by DLS.

\subsection{Antimicrobial Activity by Biosynthesized AgNPs}

AgNPs were well-known to have strong antimicrobial activities [6]. Antimicrobial activity of biosynthesized AgNPs was shown in Figure 8. Antimicrobial activity of the biosynthesized AgNPs was investigated by growing Escherichia coli (E. coli) ATCC 10536 and Staphylococcus aureus (S. aureus) ATCC 6538 colonies on Luria-Bertani (LB) broth agar plates. As shown in Figure 8A, significant inhibition zone of E. coli was observed with the colonies treated with AgNPs, as compared to those treated with aqueous extract of Ecklonia cava alone. It was also clearly observed that biosynthesized AgNPs revealed a concentration-dependent antibacterial activity. E. coli colonies treated with $40 \mu \mathrm{g}$ of AgNPs exhibited a larger diameter of zone of inhibition (12 $\pm 1 \mathrm{~mm}$ ) (Figure $8(\mathrm{Ad})$ ), as compared to those treated with $20 \mu \mathrm{g}$ of AgNPs $(10 \pm 1 \mathrm{~mm}$ ) (Figure 8(Ac)). Efficient antimicrobial activity of the biosynthesized AgNPs was also observed with S. aureus. The S. aureus colonies treated with $40 \mu \mathrm{g}$ of AgNPs exhibited a larger diameter of zone of inhibition (Figure $8(\mathrm{Bd})$ ), as compared to those treated with aqueous extract of Ecklonia cava alone (Figure 8(Bb)). It was reported that synthesized AgNPs with Rhus chinensis extracts exhibited efficient antimicrobial activity against S. aureus, Staphylococcus saprophyticus, E. coli, and Pseudomonas aeruginosa [61]. This study used $50 \mu \mathrm{g}$ to $70 \mu \mathrm{g}$ of AgNPs to achieve good antibacterial activity against all of the tested bacteria. In this study, effective antimicrobial activity was achieved by using only $40 \mu \mathrm{g}$ of biosynthesized AgNPs, demonstrating a higher antimicrobial activity of the biosynthesized AgNPs using Ecklonia cava extracts. Half maximal effective concentration $\left(\mathrm{EC}_{50}\right)$ of AgNPs against $E$. coli was found to be $15.2 \mu \mathrm{g} / \mathrm{mL}$, whereas a slightly higher $\mathrm{EC}_{50}$ (i.e., $16.2 \mu \mathrm{g} / \mathrm{mL}$ ) was required for $S$. aureus.

Although AgNPs have demonstrated effective antimicrobial activities, the mechanism of action on microorganisms has not been clearly elucidated yet. It has been proposed that silver ions released 
from AgNPs can interact with thiol groups present in respiratory enzymes of bacterial cells, thus disrupting their respiration process [81]. Another possible mechanism of cell death is the interaction of silver ions with bases and phosphorus groups of DNA, leading to the inhibition of DNA replication and thus cell death [82].

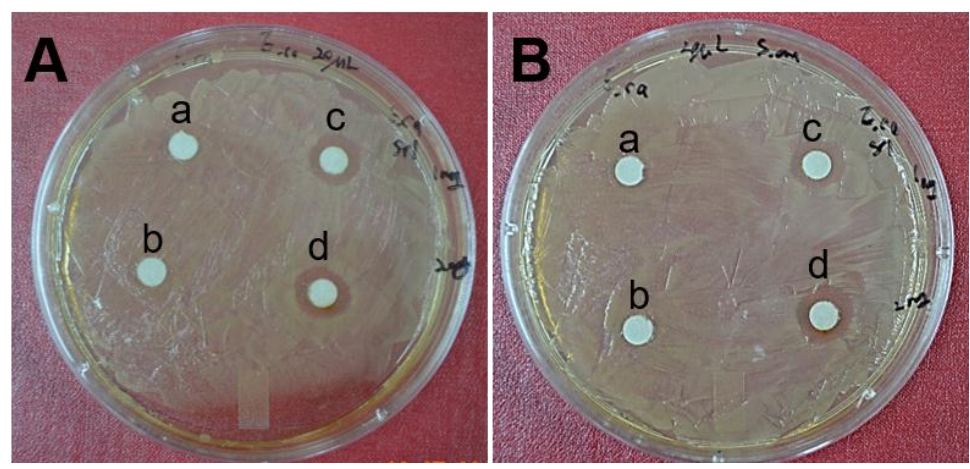

Figure 8. Antimicrobial activity of biosynthesized AgNPs, determined by an agar well diffusion assay. Pictures show inhibition zones produced by the biosynthesized AgNPs against E. coli and S. aureus. (A) E. coli colonies treated with: (a) $20 \mu \mathrm{g}$ of aqueous extract of Ecklonia cava; (b) $40 \mu \mathrm{g}$ of aqueous extract of Ecklonia cava; (c) $20 \mu \mathrm{g}$ of AgNPs; and (d) $40 \mu \mathrm{g}$ of AgNPs. (B) S. aureus colonies treated with: (a) $20 \mu \mathrm{g}$ of aqueous extract of Ecklonia cava; (b) $40 \mu \mathrm{g}$ of aqueous extract of Ecklonia cava; (c) $20 \mu \mathrm{g}$ of AgNPs; and (d) $40 \mu \mathrm{g}$ of AgNPs.

\subsection{Antioxidant Activity by Biosynthesized AgNPs}

Antioxidant activity of biosynthesized AgNPs was evaluated by 1,1-diphenyl-2-picrylhydrazyl (DPPH) radical scavenging assay (Figure 9). Free radical scavenging activity of AgNPs was determined by a decrease in absorbance of DPPH solution at $517 \mathrm{~nm}$. When DPPH solution was mixed with $250 \mu \mathrm{g} / \mathrm{mL}$ of Ecklonia cava extract or biosynthesized AgNPs, ca. 50\% of scavenging activity was achieved (Figure 9). DPPH radical scavenging activities of Ecklonia cava extract and biosynthesized AgNPs were similar at the same concentrations (e.g., 100, 250, and $500 \mu \mathrm{g} / \mathrm{mL}$ ). High antioxidant activity of Ecklonia cava extract is possibly due to polyphenolic compounds, as previously reported [67]. This result indicates that strong antioxidant activity of biosynthesized AgNPs is highly related to the Ecklonia cava extract remained on the surface of the AgNPs. Due to the efficient antioxidant activities of both Ecklonia cava extracts and AgNPs, combination of AgNPs and Ecklonia cava with synergistic effects can be a good candidate as pharmaceutical and nutraceutical products.

Ecklonia cava extracts

$\infty$ AgNPs

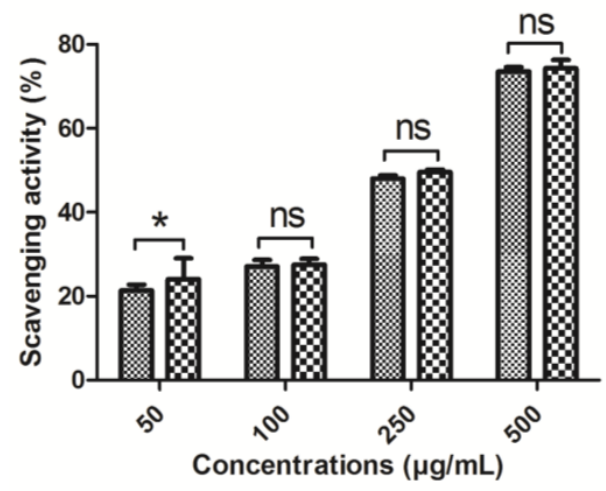

Figure 9. 1,1-diphenyl-2-picrylhydrazyl (DPPH) radical scavenging activity of Ecklonia cava extract and biosynthesized AgNPs. (ns: non-significant; ${ }^{*} p<0.05$ ). 


\subsection{Anticancer Activity by Biosynthesized AgNPs}

In recent years, searching anticancer drug candidates from marine resources is increasing due to their lower side effects [83,84]. Anticancer activity of biosynthesized AgNPs using Ecklonia cava extracts was investigated by using human cervical cancer cells (HeLa cells). Figure 10A shows the cytotoxicity of AgNPs at different concentrations. $\mathrm{IC}_{50}$ value of the AgNPs was found to be around $59 \mu \mathrm{g} / \mathrm{mL}$. The cells treated with aqueous extract of Ecklonia cava alone did not show any noticeable cytotoxicity at high concentrations such as $250 \mu \mathrm{g} / \mathrm{mL}$ (data not shown). A similar anticancer capability of biosynthesized AgNPs against HeLa cells was found in other recent studies [85]. Biosynthesized AgNPs using Podophyllum hexandrum exhibited an efficient anticancer activity against HeLa cells with an $\mathrm{IC}_{50}$ value of $20 \mu \mathrm{g} / \mathrm{mL}$. High cytotoxic effect of biosynthesized AgNPs using Cymodocea serrulata was also reported [86]. Their $\mathrm{IC}_{50}$ value against HeLa cells was $34.5 \mu \mathrm{g} / \mathrm{mL}$.
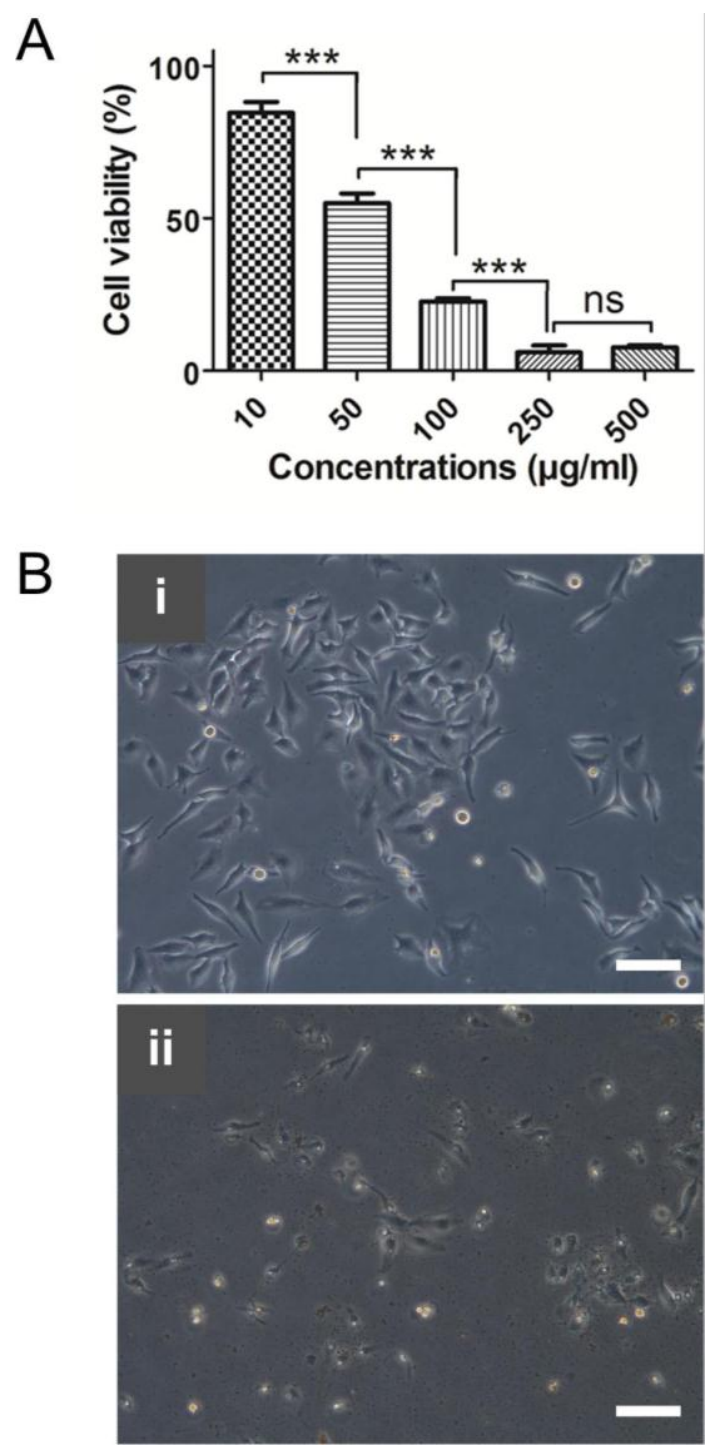

Figure 10. (A) Anticancer activity of biosynthesized AgNPs against HeLa cells (ns: non-significant; *** $p<0.001$ ); and (B) optical microscopy images of HeLa cells after treatment with: (i) $250 \mu \mathrm{g} / \mathrm{mL}$ of Ecklonia cava extracts; and (ii) AgNPs. Scale bars $=100 \mu \mathrm{m}$.

Morphologies of HeLa cells after treatment with Ecklonia cava extracts and biosynthesized AgNPs at $250 \mu \mathrm{g} / \mathrm{mL}$ of concentration were observed. The cells treated with Ecklonia cava extracts did not 
show any dramatic morphological changes, whereas AgNPs led to significant morphological changes, attributed to the rupture of the membrane (Figure 10B).

\subsection{Apoptosis Assay}

Apoptosis of HeLa cells treated with biosynthesized AgNPs at $250 \mu \mathrm{g} / \mathrm{mL}$ concentration was investigated using Annexin V-FITC/PI staining. The result of live cells (Annexin $\mathrm{V}^{-}, \mathrm{PI}^{-}$), necrotic cells (Annexin $\mathrm{V}^{-}, \mathrm{PI}^{+}$), early apoptotic cells (Annexin $\mathrm{V}^{+}, \mathrm{PI}^{-}$), and late apoptotic/dead cells (Annexin $\mathrm{V}^{+}$, $\mathrm{PI}^{+}$) is represented in Figure 11. As shown in Figure 11A,B, both untreated cells and Ecklonia cava extracts-treated cells remained almost viable, indicated by Annexin $\mathrm{V}^{-}$and $\mathrm{PI}^{-}$staining. Negligible amount of the cells underwent apoptosis. In contrast, a significant increase in the population of early apoptotic cells was detected when the cells were treated with biosynthesized AgNPs at $250 \mu \mathrm{g} / \mathrm{mL}$ concentration, as indicated by positive staining for Annexin $\mathrm{V}$ and negative staining for PI $(17.28 \%$ in the lower right quadrant) (Figure 11C,D). In addition, there was an increase in the population of necrotic cells (1.73\% in the upper right quadrant) for the cells treated with biosynthesized AgNPs (Figure 11C,D). This result indicates that anticancer activity of the biosynthesized AgNPs against HeLa cells are closely associated with their apoptosis induction. Similar results were reported in a previous study. AgNPs synthesized with Moringa oleifera showed a high anticancer activity against HeLa cells in a dose-dependent manner [8]. A significantly increased amount of the cells was identified as early apoptotic cells after treatment with the AgNPs, confirming the direct anticancer effect of apoptosis induced by the AgNPs.
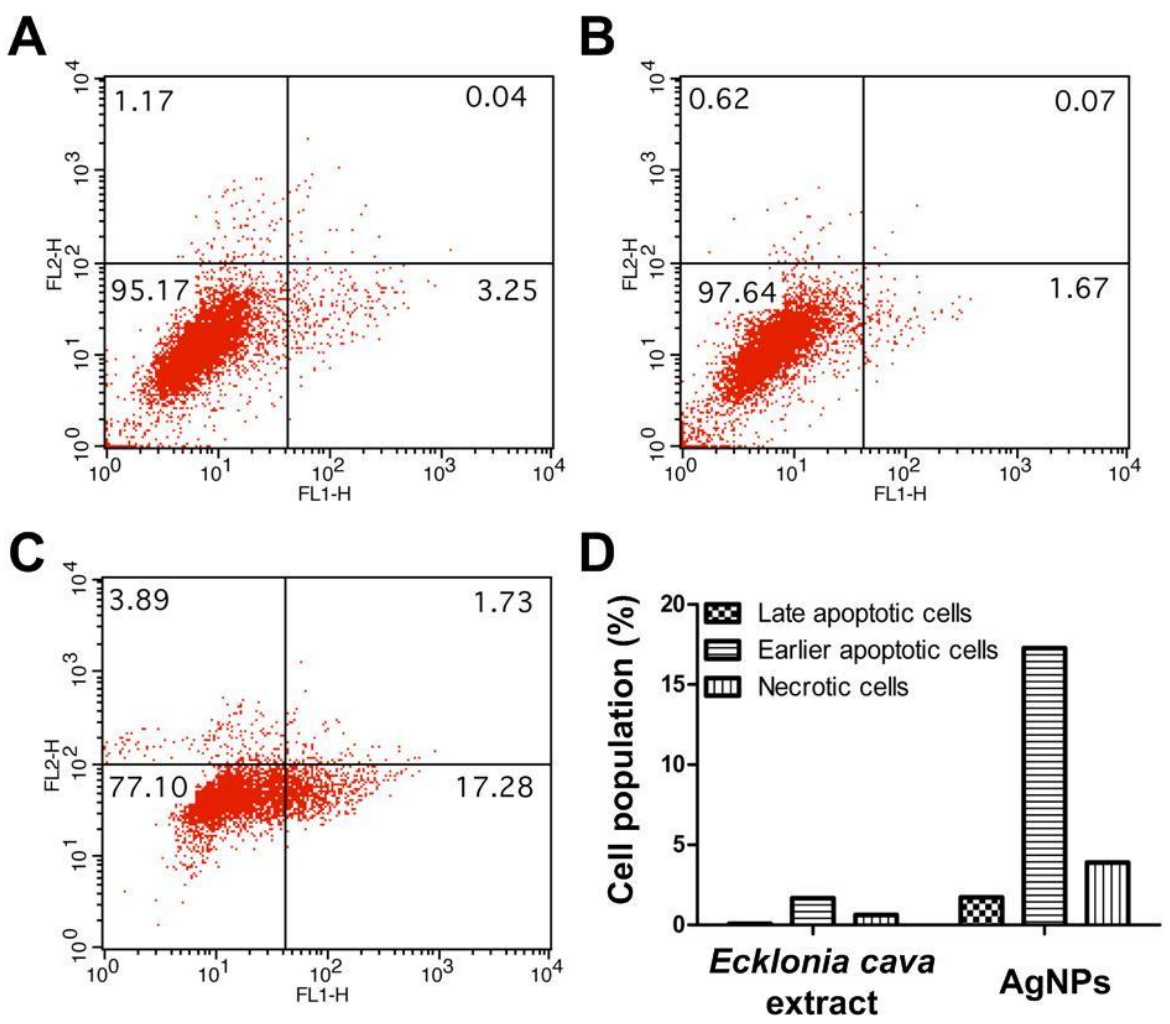

Figure 11. Annexin/PI staining of: (A) untreated HeLa cells; (B) HeLa cells treated with $250 \mu \mathrm{g} / \mathrm{mL}$ of Ecklonia cava extracts; (C) HeLa cells treated with $250 \mu \mathrm{g} / \mathrm{mL}$ of biosynthesized AgNPs; and (D) relative cell population of HeLa cells after treatment with Ecklonia cava extracts and biosynthesized AgNPs. 


\section{Materials and Methods}

\subsection{Materials}

Ecklonia cava powder was obtained from Jeju Island, Korea. Further fined powders after grinding were used in this study. Silver nitrate $\left(\mathrm{AgNO}_{3}\right)$ and 1,1-diphenyl-2-picryl-hydrazyl (DPPH), [3-(4,5-dimethylthiazol-2-yl)-2,5-diphenyltetrazolium bromide] (MTT) were purchased from Sigma Aldrich (St. Louis, MO, USA). Escherichia coli ATCC 10536 and Staphylococcus aureus ATCC 6538 were purchased from Korean culture of center of microorganisms, South Korea. Luria-Bertani broth (USB Corporation, Cleveland, OH, USA) and agar (LAB M Limited, Bury, UK) were used. HeLa cells were purchased from ATCC (Manassas, VA, USA). Dulbecco's modified eagle medium (DMEM) and fetal bovine serum (FBS) were obtained from Lonza Chemicals. Other chemicals were used in this experiment are analytical grades.

\subsection{Preparation of Aqueous Extract of Ecklonia cava and Biosynthesis of AgNPs}

Five grams of Ecklonia cava powder were mixed with $500 \mathrm{~mL}$ of deionized water at $100{ }^{\circ} \mathrm{C}$ for $1 \mathrm{~h}$. The homogeneous solution was then centrifuged at $3000 \mathrm{rpm}$ for $20 \mathrm{~min}$, and the large particles were settled down at the bottom of the conical tube. The clear brown color solution was decanted and filtered through a filter paper. The filtrate was then stored at $4{ }^{\circ} \mathrm{C}$ until the next use. Ten milliliters of aqueous extract of Ecklonia cava was taken and mixed with $90 \mathrm{~mL}$ of $1 \mathrm{mM} \mathrm{AgNO}$ solution. A color change from yellow to dark brown indicates the formation of AgNPs by reducing $\mathrm{Ag}^{+}$to $\mathrm{Ag}^{0}$. The dark brown color mixture solution was stirred for $72 \mathrm{~h}$. The biosynthesized AgNPs were lyophilized and stored until to the next use.

\subsection{UV-Visible Spectroscopy}

Reduction of silver ions by aqueous extract of Ecklonia cava was monitored using UV-visible spectroscopy. An aliquot of the reaction mixture was collected periodically and scanned using a spectrophotometer (GeneQuant 1300, GE Healthcare, Piscataway, NJ, USA) at wavelengths between 200 and $800 \mathrm{~nm}$ with a resolution of $1 \mathrm{~nm}$.

\subsection{Thermogravimetric Analysis}

A Perkin-Elmer model of TGA-7 thermogravimetric system with a microprocessor driven temperature control unit and a TA data station was used. The mass of the samples was generally in the range of 2-3 mg. The sample pan was placed in the balance system equipment, and the temperature was raised from 50 to $700{ }^{\circ} \mathrm{C}$ at a heating rate of $10{ }^{\circ} \mathrm{C}$ per minute under nitrogen with a flow rate of $50 \mathrm{~cm}^{3} / \mathrm{min}$. The mass of the sample pan was continuously recorded as a function of temperature.

\subsection{Fourier Transform-Infrared Spectroscopy}

Functional groups and chemical compositions of AgNPs were analyzed using a FT-IR spectrometer (Nicolet iS10, Thermo Electron Scientific Instruments LLC, Madison, WI, USA). FT-IR analysis of the dried AgNPs was performed in the attenuated total reflectance (ATR) mode, and the spectra were obtained in the range of $4000-400 \mathrm{~cm}^{-1}$.

\subsection{X-ray Diffraction Analysis}

XRD measurement was performed on a Philips X'Pert-MPD diffractometer (Philips, Almelo, The Netherlands) with $\mathrm{Cu} \mathrm{K} \alpha$ radiation $(\lambda=1.540 \AA)$ at $30 \mathrm{~mA}$ and $40 \mathrm{kV}$. The scan was performed in the $2 \theta$ range from $5^{\circ}$ to $80^{\circ}$ at the scanning rate of $2^{\circ} / \mathrm{min}$. 


\subsection{Transmission Electron Microscopy (TEM) and Dynamic Light Scattering (DLS) Analysis}

Size and surface morphology of biosynthesized AgNPs were measured using a transmission electron microscope (TEM, H7500, Hitachi Ltd., Tokyo, Japan) at 120 kV. TEM grids were prepared by placing $5 \mu \mathrm{L}$ of the AgNPs solution on carbon-coated copper grids and dried. Size distribution of the AgNPs was characterized by dynamic light scattering using a Malvern Zetasizer Nano ZS (Worcestershire, UK).

\subsection{Agar Well Diffusion Assay}

Antimicrobial activity of biosynthesized AgNPs against microorganisms was assessed by an agar well diffusion method as previously described [61]. Briefly, both Escherichia coli and Staphylococcus aureus were cultured in $3 \mathrm{~mL}$ of Luria-Bertani broth. Bacteria concentration was determined by optical densities at $600 \mathrm{~nm}$. Around $0.2 \times 10^{8} \mathrm{CFU}$ of bacteria in culture broth were plated on petri dishes. We prepared the stock $(1 \mathrm{mg} / \mathrm{mL})$ of the lyophilized Ecklonia cava and AgNPs. Then four paper disks containing 20 or $40 \mu \mathrm{L}$ (equivalent to $20 \mu \mathrm{g}$ and $40 \mu \mathrm{g}$ ) of synthesized AgNPs were placed carefully on the microbial plate. The paper disk containing aqueous extract of Ecklonia cava only was also used as a control group. The bacteria on the petri dishes were cultured for $24 \mathrm{~h}$ at $37^{\circ} \mathrm{C}$, and the antimicrobial activity of the AgNPs was measured by inhibition zones.

An MTT assay was used to determine antibacterial activities of Ecklonia cava extracts and AgNPs. Five hundred microliters of diluted bacteria culture $\left(1 \times 10^{6} \mathrm{CFU} / \mathrm{mL}\right)$ was treated with different concentrations $(0,10,20,30,40$ and $50 \mu \mathrm{g} / \mathrm{mL})$ of Ecklonia cava extracts and AgNPs and kept in a shaking incubator at $37^{\circ} \mathrm{C}$ for $24 \mathrm{~h}$. Subsequently, $50 \mu \mathrm{L}$ of MTT solution $(5 \mathrm{mg} / \mathrm{mL})$ was added into the samples to form formazan crystas within live bacteria. Then, the samples were centrifuged at $8000 \mathrm{rpm}$ for $10 \mathrm{~min}$ to separate the formazan crystals. The supernatant was eliminated, and $1000 \mu \mathrm{L}$ of dimethyl sulfoxide (DMSO) was added to dissolve the formazan crystals. Antibacterial activities were determined by measuring the absorbance of the formazan solution at $540 \mathrm{~nm}$.

\subsection{DPPH Radical Scavenging Assay}

Free radical scavenging activity of Ecklonia cava extracts and biosynthesized AgNPs were measured using a conventional DPPH radical scavenging assay [87]. Briefly, $0.1 \mathrm{mM}$ DPPH solution in ethanol was prepared, and different concentrations of Ecklonia cava extracts and AgNPs (e.g., 50, 100,250 , and $500 \mu \mathrm{g} / \mathrm{mL}$ ) were mixed with DPPH solution to attain the final respective concentration. DPPH solution without sample was used as a blank. The mixture solution was vortex-mixed and then incubated for $30 \mathrm{~min}$ at $37^{\circ} \mathrm{C}$. Then the mixture solution was centrifuged at $3000 \mathrm{rpm}$ for $5 \mathrm{~min}$, and the absorbance of the supernatant liquid was measured at $517 \mathrm{~nm}$ using a microplate reader $\left(\right.$ GENios $^{\circledR}$, Tecan Austria GmbH, Grödig, Austria). DPPH scavenging activity (\%) was calculated using the following formula:

$$
\text { DPPH scavenging activity }(\%)=\frac{(\text { Absorbance of blank sample }- \text { Absorbance of treated sample })}{\text { Absorbance of blank sample }} \times 100
$$

\subsection{Cytotoxicity Assay}

HeLa cells were cultured with DMEM media supplemented with 10\% FBS, penicillin (100 IU /mL), and streptomycin $(100 \mu \mathrm{g} / \mathrm{mL})$. The cells were initially seeded into a 24-well plate at the density of $5 \times 10^{4}$ per well. After $24 \mathrm{~h}$ of incubation at $37^{\circ} \mathrm{C}$, the cells were treated with different concentrations of AgNPs $(0-500 \mu \mathrm{g} / \mathrm{mL})$. After further incubation for $24 \mathrm{~h}$ at $37^{\circ} \mathrm{C}$, cytotoxicity effect of AgNPs on the cells was measured using an MTT assay. Briefly, the cells were incubated with $1 \mathrm{~mL}$ of MTT solution $(1 \mathrm{mg} / \mathrm{mL})$ for $4 \mathrm{~h}$. Then, $1 \mathrm{~mL}$ of dimethyl sulfoxide was added to solubilize the formed MTT formazan. Cell viability was determined by measuring the absorbance of the formazan products at $540 \mathrm{~nm}$ using a microplate reader. Measurements were performed in triplicates, and the concentration of AgNPs that can induce $50 \%$ of cytotoxicity was determined graphically. 


\subsection{Optical Microscopy Analysis}

HeLa cells $\left(2 \times 10^{5}\right.$ cells /well) were cultured in six-well plates. After $24 \mathrm{~h}$ of incubation, cells were treated with aqueous extract of Ecklonia cava $(250 \mu \mathrm{g} / \mathrm{mL})$ and AgNPs, respectively. After $6 \mathrm{~h}$ of incubation, morphologies of the cells were observed using an optical microscope (CTR 6000, Leica, Wetzlar, Germany).

\subsection{Annexin V-FITC/Propidium Iodide (PI) Staining}

HeLa cells were seeded into six-well plates at $3 \times 10^{5}$ cells per well and cultured for $24 \mathrm{~h}$ at $37^{\circ} \mathrm{C}$. The cells were then treated with aqueous extract of Ecklonia cava and AgNPs at $250 \mu \mathrm{g} / \mathrm{mL}$ concentrations, followed by incubation for $4 \mathrm{~h}$. After the cells were trypsinized, they were resuspended in $100 \mu \mathrm{L}$ of Annexin V binding buffer and then stained with Annexin V and PI solution according to the manufacturer's protocol (BD Biosciences, Heidelberg, Germany). The mean fluorescence intensities from the stained cells were measured using a flow cytometer (FACS Calibur, BD Biosciences). The results were expressed as a percentage of live cells (Annexin $\mathrm{V}^{-}, \mathrm{PI}^{-}$) necrotic cells (Annexin $\mathrm{V}^{-}, \mathrm{PI}^{+}$), early apoptotic cells (Annexin $\mathrm{V}^{+}, \mathrm{PI}^{-}$), and late apoptotic/dead cells (Annexin $\mathrm{V}^{+}, \mathrm{PI}^{+}$). The percentage of apoptotic cells after treatment with AgNPs was compared to that of untreated cells.

\subsection{Statistical Analysis}

All the experiments were performed in triplicates. Data were analyzed using one-way analysis of variance (ANOVA) on the significance level of $p<0.01$ and presented as mean \pm standard deviation.

\section{Conclusions}

AgNPs were successfully synthesized using marine algae Ecklonia cava via a simple and eco-friendly green approach for the first time. The formation of AgNPs was confirmed by UV-Vis spectroscopy. The biosynthesized AgNPs were spherical and crystalline, with an average size of $43 \mathrm{~nm}$. The biosynthesized AgNPs exhibited an efficient antibacterial efficacy in a dose-dependent manner. They also showed an efficient antioxidant activity with an $\mathrm{IC}_{50}$ value of $198 \mu \mathrm{g} / \mathrm{mL}$ for DPPH. Furthermore, they greatly induced apoptosis and led to the consequent anticancer effect against human cervical cancer cells. This study demonstrates that eco-friendly and simple green synthesis of AgNPs using Ecklonia cava extracts could be a competitive alternative to conventional chemical methods. It is also suggested that the biosynthesized AgNPs with efficient antimicrobial, antioxidant, and anticancer activities hold huge potential for pharmaceutical, nutraceutical, and cosmeceutical applications.

Acknowledgments: This work was supported by the Incheon National University Research Grant in 2013. We thank Mr. Dong Seop Kang (Marine Techno Inc., Korea) for experimental assistance with an agar well diffusion assay.

Author Contributions: J.V. and S.-K.K. conceived and designed the experiments. J.V. performed the experiments. J.V. and M.S.S. analyzed the data and wrote the manuscript.

Conflicts of Interest: The authors declare no conflict of interest.

\section{References}

1. Chen, G.; Roy, I.; Yang, C.; Prasad, P.N. Nanochemistry and nanomedicine for nanoparticle-based diagnostics and therapy. Chem. Rev. 2016, 116, 2826-2885. [CrossRef] [PubMed]

2. Xie, J.; Lee, S.; Chen, X. Nanoparticle-based theranostic agents. Adv. Drug Deliv. Rev. 2010, 62, $1064-1079$. [CrossRef] [PubMed]

3. Yavuz, M.S.; Cheng, Y.; Chen, J.; Cobley, C.M.; Zhang, Q.; Rycenga, M.; Xie, J.; Kim, C.; Song, K.H.; Schwartz, A.G. Gold nanocages covered by smart polymers for controlled release with near-infrared light. Nat. Mater. 2009, 8, 935-939. [CrossRef] [PubMed]

4. Vial, S.; Reis, R.L.; Oliveira, J.M. Recent advances using gold nanoparticles as a promising multimodal tool for tissue engineering and regenerative medicine. Curr. Opin. Solid State Mater. Sci. 2016. [CrossRef] 
5. Rauwel, P.; Rauwel, E.; Ferdov, S.; Singh, M.P. Silver nanoparticles: Synthesis, properties, and applications. Adv. Colloid Interface Sci. 2015, 2015, 624394. [CrossRef]

6. Krishnaraj, C.; Jagan, E.; Rajasekar, S.; Selvakumar, P.; Kalaichelvan, P.; Mohan, N. Synthesis of silver nanoparticles using Acalypha indica leaf extracts and its antibacterial activity against water borne pathogens. Colloids Surf. B 2010, 76, 50-56. [CrossRef] [PubMed]

7. AshaRani, P.V.; Low Kah Mun, G.; Hande, M.P.; Valiyaveettil, S. Cytotoxicity and genotoxicity of silver nanoparticles in human cells. ACS Nano 2009, 3, 279-290. [CrossRef] [PubMed]

8. Vasanth, K.; Ilango, K.; MohanKumar, R.; Agrawal, A.; Dubey, G.P. Anticancer activity of Moringa oleifera mediated silver nanoparticles on human cervical carcinoma cells by apoptosis induction. Colloids Surf. B 2014, 117, 354-359. [CrossRef] [PubMed]

9. Gengan, R.; Anand, K.; Phulukdaree, A.; Chuturgoon, A. A549 lung cell line activity of biosynthesized silver nanoparticles using Albizia adianthifolia leaf. Colloids Surf. B 2013, 105, 87-91. [CrossRef] [PubMed]

10. Farah, M.A.; Ali, M.A.; Chen, S.-M.; Li, Y.; Al-Hemaid, F.M.; Abou-Tarboush, F.M.; Al-Anazi, K.M.; Lee, J. Silver nanoparticles synthesized from Adenium obesum leaf extract induced DNA damage, apoptosis and autophagy via generation of reactive oxygen species. Colloids Surf. B 2016, 141, 158-169. [CrossRef] [PubMed]

11. Helmlinger, J.; Sengstock, C.; Groß-Heitfeld, C.; Mayer, C.; Schildhauer, T.; Köller, M.; Epple, M. Silver nanoparticles with different size and shape: Equal cytotoxicity, but different antibacterial effects. RSC Adv. 2016, 6, 18490-18501. [CrossRef]

12. Mondal, S.; Roy, N.; Laskar, R.A.; Sk, I.; Basu, S.; Mandal, D.; Begum, N.A. Biogenic synthesis of Ag, Au and bimetallic $\mathrm{Au} / \mathrm{Ag}$ alloy nanoparticles using aqueous extract of mahogany (Swietenia mahogani JACQ.) leaves. Colloids Surf. B 2011, 82, 497-504. [CrossRef] [PubMed]

13. Fayaz, A.M.; Balaji, K.; Girilal, M.; Yadav, R.; Kalaichelvan, P.T.; Venketesan, R. Biogenic synthesis of silver nanoparticles and their synergistic effect with antibiotics: A study against gram-positive and gram-negative bacteria. Nanomed. Nanotechnol. Biol. Med. 2010, 6, 103-109. [CrossRef] [PubMed]

14. Sun, Y.; Yin, Y.; Mayers, B.T.; Herricks, T.; Xia, Y. Uniform silver nanowires synthesis by reducing $\mathrm{AgNO}_{3}$ with ethylene glycol in the presence of seeds and poly(vinyl pyrrolidone). Chem. Mater. 2002, 14, 4736-4745. [CrossRef]

15. Yin, B.; Ma, H.; Wang, S.; Chen, S. Electrochemical synthesis of silver nanoparticles under protection of poly(N-vinylpyrrolidone). J. Phys. Chem. B 2003, 107, 8898-8904. [CrossRef]

16. Dimitrijevic, N.M.; Bartels, D.M.; Jonah, C.D.; Takahashi, K.; Rajh, T. Radiolytically induced formation and optical absorption spectra of colloidal silver nanoparticles in supercritical ethane. J. Phys. Chem. B 2001, 105, 954-959. [CrossRef]

17. Iravani, S. Green synthesis of metal nanoparticles using plants. Green Chem. 2011, 13, 2638-2650. [CrossRef]

18. Wang, H.; Qiao, X.; Chen, J.; Wang, X.; Ding, S. Mechanisms of PVP in the preparation of silver nanoparticles. Mater. Chem. Phys. 2005, 94, 449-453. [CrossRef]

19. Roy, N.; Mondal, S.; Laskar, R.A.; Basu, S.; Mandal, D.; Begum, N.A. Biogenic synthesis of Au and Ag nanoparticles by indian propolis and its constituents. Colloids Surf. B 2010, 76, 317-325. [CrossRef] [PubMed]

20. Alam, M.N.; Roy, N.; Mandal, D.; Begum, N.A. Green chemistry for nanochemistry: Exploring medicinal plants for the biogenic synthesis of metal NPs with fine-tuned properties. RSC Adv. 2013, 3, 11935-11956. [CrossRef]

21. Chung, I.M.; Park, I.; Seung-Hyun, K.; Thiruvengadam, M.; Rajakumar, G. Plant-mediated synthesis of silver nanoparticles: Their characteristic properties and therapeutic applications. Nanoscale Res. Lett. 2016, 11, 40. [CrossRef] [PubMed]

22. Merin, D.D.; Prakash, S.; Bhimba, B.V. Antibacterial screening of silver nanoparticles synthesized by marine micro algae. Asian Pac. J. Trop. Med. 2010, 3, 797-799. [CrossRef]

23. Verma, V.C.; Kharwar, R.N.; Gange, A.C. Biosynthesis of antimicrobial silver nanoparticles by the endophytic fungus Aspergillus clavatus. Nanomedicine 2010, 5, 33-40. [CrossRef] [PubMed]

24. Venkatpurwar, V.; Pokharkar, V. Green synthesis of silver nanoparticles using marine polysaccharide: Study of in vitro antibacterial activity. Mater. Lett. 2011, 65, 999-1002. [CrossRef]

25. Vivek, M.; Kumar, P.S.; Steffi, S.; Sudha, S. Biogenic silver nanoparticles by Gelidiella acerosa extract and their antifungal effects. Avicenna J. Med. Biotechnol. 2011, 3, 143-148. [PubMed] 
26. Kumar, P.; Senthamil Selvi, S.; Lakshmi Prabha, A.; Prem Kumar, K.; Ganeshkumar, R.; Govindaraju, M. Synthesis of silver nanoparticles from Sargassum tenerrimum and screening phytochemicals for its antibacterial activity. Nano Biomed. Eng. 2012, 4, 12-16. [CrossRef]

27. Rajesh, S.; Raja, D.P.; Rathi, J.; Sahayaraj, K. Biosynthesis of silver nanoparticles using Ulva fasciata (Delile) ethyl acetate extract and its activity against Xanthomonas campestris pv. malvacearum. J. Biopest. 2012, 5, 119-128.

28. Rajeshkumar, S.; Kannan, C.; Annadurai, G. Synthesis and characterization of antimicrobial silver nanoparticles using marine brown seaweed Padina tetrastromatica. Drug Invent. Today 2012, 4, 511-513.

29. Rajeshkumar, S.; Kannan, C.; Annadurai, G. Green synthesis of silver nanoparticles using marine brown algae Turbinaria conoides and its antibacterial activity. Int. J. Pharm. Biol. Sci. 2012, 3, 502-510.

30. Sahayaraj, K.; Rajesh, S.; Rathi, J. Silver nanoparticles biosynthesis using marine algae Padina pavonica (Linn.) and its microbial activity. Dig. J. Nanomater. Biostruct. 2012, 7, 1557-1567.

31. Dar, M.A.; Ingle, A.; Rai, M. Enhanced antimicrobial activity of silver nanoparticles synthesized by Cryphonectria sp. evaluated singly and in combination with antibiotics. Nanomed. Nanotechnol. Biol. Med. 2013, 9, 105-110. [CrossRef] [PubMed]

32. El-Rafie, H.; El-Rafie, M.; Zahran, M. Green synthesis of silver nanoparticles using polysaccharides extracted from marine macro algae. Carbohydr. Polym. 2013, 96, 403-410. [CrossRef] [PubMed]

33. Kumar, P.; Selvi, S.S.; Govindaraju, M. Seaweed-mediated biosynthesis of silver nanoparticles using Gracilaria corticata for its antifungal activity against Candida spp. Appl. Nanosci. 2013, 3, 495-500. [CrossRef]

34. Mohandass, C.; Vijayaraj, A.; Rajasabapathy, R.; Satheeshbabu, S.; Rao, S.; Shiva, C.; De-Mello, I. Biosynthesis of silver nanoparticles from marine seaweed Sargassum cinereum and their antibacterial activity. Indian J. Pharm. Sci. 2013, 75, 606-610. [PubMed]

35. Shiny, P.; Mukherjee, A.; Chandrasekaran, N. Marine algae mediated synthesis of the silver nanoparticles and its antibacterial efficiency. Int. J. Pharm. Pharm. Sci. 2013, 5, 239-241.

36. Dhas, T.S.; Kumar, V.G.; Karthick, V.; Angel, K.J.; Govindaraju, K. Facile synthesis of silver chloride nanoparticles using marine alga and its antibacterial efficacy. Spectrochim. Acta Mol. Biomol. Spectrosc. 2014, 120, 416-420. [CrossRef] [PubMed]

37. Rajeshkumar, S.; Malarkodi, C.; Paulkumar, K.; Vanaja, M.; Gnanajobitha, G.; Annadurai, G. Algae mediated green fabrication of silver nanoparticles and examination of its antifungal activity against clinical pathogens. Int. J. Met. 2014, 2014, 692643. [CrossRef]

38. Sinha, S.N.; Paul, D.; Halder, N.; Sengupta, D.; Patra, S.K. Green synthesis of silver nanoparticles using fresh water green alga Pithophora oedogonia (Mont.) wittrock and evaluation of their antibacterial activity. Appl. Nanosci. 2015, 5, 703-709. [CrossRef]

39. Ajitha, B.; Ashok Kumar Reddy, Y.; Rajesh, K.M.; Sreedhara Reddy, P. Sesbania grandiflora leaf extract assisted green synthesis of silver nanoparticles: Antimicrobial activity. Mater. Today Proc. 2016, 3, 1977-1984. [CrossRef]

40. Oves, M.; Khan, M.S.; Zaidi, A.; Ahmed, A.S.; Ahmed, F.; Ahmad, E.; Sherwani, A.; Owais, M.; Azam, A. Antibacterial and cytotoxic efficacy of extracellular silver nanoparticles biofabricated from chromium reducing novel OS4 strain of Stenotrophomonas maltophilia. PLoS ONE 2013, 8, e59140. [CrossRef] [PubMed]

41. Khanra, K.; Panja, S.; Choudhuri, I.; Chakraborty, A.; Bhattacharyya, N. Antimicrobial and cytotoxicity effect of silver nanoparticle synthesized by Croton bonplandianum Baill. leaves. Nanomed. J. 2016, 3, 15-22.

42. Abdel-Aziz, M.S.; Shaheen, M.S.; El-Nekeety, A.A.; Abdel-Wahhab, M.A. Antioxidant and antibacterial activity of silver nanoparticles biosynthesized using Chenopodium murale leaf extract. J. Saudi Chem. Soc. 2014, 18, 356-363. [CrossRef]

43. Lalitha, P. Apoptotic efficacy of biogenic silver nanoparticles on human breast cancer MCF-7 cell lines. Prog. Biomater. 2015, 4, 113-121.

44. Gopinath, V.; Priyadarshini, S.; Loke, M.F.; Arunkumar, J.; Marsili, E.; MubarakAli, D.; Velusamy, P.; Vadivelu, J. Biogenic synthesis, characterization of antibacterial silver nanoparticles and its cell cytotoxicity. Arabian J. Chem. 2015. [CrossRef]

45. Satyavani, K.; Gurudeeban, S.; Ramanathan, T.; Balasubramanian, T. Biomedical potential of silver nanoparticles synthesized from calli cells of Citrullus colocynthis (L.) Schrad. J. Nanobiotechnol. 2011, 9, 43. 
46. Ebrahiminezhad, A.; Bagheri, M.; Taghizadeh, S.-M.; Berenjian, A.; Ghasemi, Y. Biomimetic synthesis of silver nanoparticles using microalgal secretory carbohydrates as a novel anticancer and antimicrobial. Adv. Nat. Sci. Nanosci. Nanotechnol. 2016, 7, 015018. [CrossRef]

47. Sidjui, L.; Ponnanikajamideen, M.; Malini, M.; Famen, L.; Sindhu, R.; Chandirika, J.U.; Annadurai, G.; Folefoc, G. Lovoa trichilioides root back mediated green synthesis of silver nanoparticles and rating of its antioxidant and antibacterial activity against clinical pathogens. J. Nanosci. Technol. 2015, 2, 32-36.

48. Gandhi, N.; Sirisha, D.; Sharma, V.C. Microwave-mediated green synthesis of silver nanoparticles using Ficus elastica leaf extract and application in air pollution controlling studies. Int. J. Eng. Res. Appl. 2014, 4, 61-72.

49. Antony, J.J.; Sithika, M.A.; Joseph, T.A.; Suriyakalaa, U.; Sankarganesh, A.; Siva, D.; Kalaiselvi, S.; Achiraman, S. In vivo antitumor activity of biosynthesized silver nanoparticles using Ficus religiosa as a nanofactory in dal induced mice model. Colloids Surf. B 2013, 108, 185-190. [CrossRef] [PubMed]

50. Inbathamizh, L.; Ponnu, T.M.; Mary, E.J. In vitro evaluation of antioxidant and anticancer potential of Morinda pubescens synthesized silver nanoparticles. J. Pharm. Res. 2013, 6, 32-38. [CrossRef]

51. Kaler, A.; Jain, S.; Banerjee, U.C. Green and rapid synthesis of anticancerous silver nanoparticles by Saccharomyces boulardii and insight into mechanism of nanoparticle synthesis. Biomed. Res. Int. 2013, 2013, 872940. [CrossRef] [PubMed]

52. Niraimathi, K.L.; Sudha, V.; Lavanya, R.; Brindha, P. Biosynthesis of silver nanoparticles using Alternanthera sessilis (Linn.) extract and their antimicrobial, antioxidant activities. Colloids Surf. B 2013, 102, 288-291. [CrossRef] [PubMed]

53. Sreekanth, T.V.M.; Nagajyothi, P.; Prasad, T.N.V.K.V.; Lee, K. Green synthesis of silver nanoparticles using Citrus reticulata juice and evaluation of their antibacterial activity and cytotoxicity against melanoma-B16/F10 cells. Curr. Nanosci. 2013, 9, 457-462. [CrossRef]

54. Kathiraven, T.; Sundaramanickam, A.; Shanmugam, N.; Balasubramanian, T. Green synthesis of silver nanoparticles using marine algae Caulerpa racemosa and their antibacterial activity against some human pathogens. Appl. Nanosci. 2014, 5, 499-504. [CrossRef]

55. Salari, Z.; Danafar, F.; Dabaghi, S.; Ataei, S.A. Sustainable synthesis of silver nanoparticles using macroalgae spirogyra varians and analysis of their antibacterial activity. J. Saudi Chem. Soc. 2016, 20, 459-464. [CrossRef]

56. Yousefzadi, M.; Rahimi, Z.; Ghafori, V. The green synthesis, characterization and antimicrobial activities of silver nanoparticles synthesized from green alga Enteromorpha flexuosa (wulfen) J. Agardh. Mater. Lett. 2014, 137, 1-4. [CrossRef]

57. Patel, V.; Berthold, D.; Puranik, P.; Gantar, M. Screening of cyanobacteria and microalgae for their ability to synthesize silver nanoparticles with antibacterial activity. Biotechnol. Rep. 2015, 5, 112-119. [CrossRef]

58. Haghighi Pak, Z.; Abbaspour, H.; Karimi, N.; Fattahi, A. Eco-friendly synthesis and antimicrobial activity of silver nanoparticles using Dracocephalum moldavica seed extract. Appl. Sci. 2016, 6, 69. [CrossRef]

59. He, Y.; Du, Z.; Ma, S.; Cheng, S.; Jiang, S.; Liu, Y.; Li, D.; Huang, H.; Zhang, K.; Zheng, X. Biosynthesis, antibacterial activity and anticancer effects against prostate cancer (PC-3) cells of silver nanoparticles using Dimocarpus Longan Lour. Peel extract. Nanoscale Res. Lett. 2016, 11, 1-10. [CrossRef] [PubMed]

60. Kayalvizhi, T.; Ravikumar, S.; Venkatachalam, P. Green synthesis of metallic silver nanoparticles using Curculigo orchioides rhizome extracts and evaluation of its antibacterial, larvicidal, and anticancer activity. J. Environ. Eng. 2016, 142, C4016002. [CrossRef]

61. Patil, M.P.; Rokade, A.A.; Ngabire, D.; Kim, G.-D. Green synthesis of silver nanoparticles using water extract from galls of Rhus chinensis and its antibacterial activity. J. Clust. Sci. 2016, 27, 1737-1750. [CrossRef]

62. Li, Y.; Qian, Z.-J.; Ryu, B.; Lee, S.-H.; Kim, M.-M.; Kim, S.-K. Chemical components and its antioxidant properties in vitro: An edible marine brown alga, Ecklonia cava. Biorg. Med. Chem. 2009, 17, 1963-1973. [CrossRef] [PubMed]

63. Choi, B.W.; Lee, H.S.; Shin, H.-C.; Lee, B.H. Multifunctional activity of polyphenolic compounds associated with a potential for alzheimer's disease therapy from Ecklonia cava. Phytother. Res. 2015, 29, 549-553. [CrossRef] [PubMed]

64. Kang, J.-I.; Kim, S.-C.; Kim, M.-K.; Boo, H.-J.; Jeon, Y.-J.; Koh, Y.-S.; Yoo, E.-S.; Kang, S.-M.; Kang, H.-K. Effect of dieckol, a component of Ecklonia cava, on the promotion of hair growth. Int. J. Mol. Sci. 2012, 13, 6407-6423. [CrossRef] [PubMed] 
65. Kang, S.-M.; Heo, S.-J.; Kim, K.-N.; Lee, S.-H.; Jeon, Y.-J. Isolation and identification of new compound, 2,7"'-phloroglucinol-6,6'-bieckol from brown algae, Ecklonia cava and its antioxidant effect. J. Funct. Foods 2012, 4, 158-166. [CrossRef]

66. Ferreres, F.; Lopes, G.; Gil-Izquierdo, A.; Andrade, P.B.; Sousa, C.; Mouga, T.; Valentão, P. Phlorotannin extracts from fucales characterized by HPLC-DAD-ESI-MS ${ }^{n}$ : Approaches to hyaluronidase inhibitory capacity and antioxidant properties. Mar. Drugs 2012, 10, 2766-2781. [CrossRef] [PubMed]

67. Athukorala, Y.; Kim, K.-N.; Jeon, Y.-J. Antiproliferative and antioxidant properties of an enzymatic hydrolysate from brown alga, Ecklonia cava. Food Chem. Toxicol. 2006, 44, 1065-1074. [CrossRef] [PubMed]

68. Kim, M.-M.; Van Ta, Q.; Mendis, E.; Rajapakse, N.; Jung, W.-K.; Byun, H.-G.; Jeon, Y.-J.; Kim, S.-K. Phlorotannins in Ecklonia cava extract inhibit matrix metalloproteinase activity. Life Sci. 2006, 79, 1436-1443. [CrossRef] [PubMed]

69. Kong, C.-S.; Kim, J.-A.; Yoon, N.-Y.; Kim, S.-K. Induction of apoptosis by phloroglucinol derivative from Ecklonia cava in MCF-7 human breast cancer cells. Food Chem. Toxicol. 2009, 47, 1653-1658. [CrossRef] [PubMed]

70. Choi, J.-G.; Kang, O.-H.; Brice, O.-O.; Lee, Y.-S.; Chae, H.-S.; Oh, Y.-C.; Sohn, D.-H.; Park, H.; Choi, H.-G.; Kim, S.-G. Antibacterial activity of Ecklonia cava against methicillin-resistant Staphylococcus aureus and Salmonella spp. Foodborne Pathog. Dis. 2010, 7, 435-441. [CrossRef] [PubMed]

71. Li, Y.; Qian, Z.-J.; Kim, M.-M.; Kim, S.-K. Cytotoxic activities of phlorethol and fucophlorethol derivatives isolated from laminariaceae Ecklonia cava. J. Food Biochem. 2011, 35, 357-369. [CrossRef]

72. Tripathy, A.; Raichur, A.M.; Chandrasekaran, N.; Prathna, T.; Mukherjee, A. Process variables in biomimetic synthesis of silver nanoparticles by aqueous extract of Azadirachta indica (Neem) leaves. J. Nanopart. Res. 2010, 12, 237-246. [CrossRef]

73. Shaligram, N.S.; Bule, M.; Bhambure, R.; Singhal, R.S.; Singh, S.K.; Szakacs, G.; Pandey, A. Biosynthesis of silver nanoparticles using aqueous extract from the compactin producing fungal strain. Process Biochem. 2009, 44, 939-943. [CrossRef]

74. Dobrucka, R.; Długaszewska, J. Antimicrobial activities of silver nanoparticles synthesized by using water extract of arnicae anthodium. Indian J. Microbiol. 2015, 55, 168-174. [CrossRef] [PubMed]

75. Eugenio, M.; Müller, N.; Frasés, S.; Almeida-Paes, R.; Lima, L.M.T.R.; Lemgruber, L.; Farina, M.; de Souza, W.; Sant'Anna, C. Yeast-derived biosynthesis of silver/silver chloride nanoparticles and their antiproliferative activity against bacteria. RSC Adv. 2016, 6, 9893-9904. [CrossRef]

76. Kang, Y.O.; Lee, T.S.; Park, W.H. Green synthesis and antimicrobial activity of silver chloride nanoparticles stabilized with chitosan oligomer. J. Mater. Sci. Mater. Med. 2014, 25, 2629-2638. [CrossRef] [PubMed]

77. Zhao, X.; Zhang, J.; Wang, B.; Zada, A.; Humayun, M. Biochemical synthesis of Ag/AgCl nanoparticles for visible-light-driven photocatalytic removal of colored dyes. Materials 2015, 8, 2043-2053. [CrossRef]

78. Kumar, V.A.; Uchida, T.; Mizuki, T.; Nakajima, Y.; Katsube, Y.; Hanajiri, T.; Maekawa, T. Synthesis of nanoparticles composed of silver and silver chloride for a plasmonic photocatalyst using an extract from a weed Solidago altissima (goldenrod). Adv. Nat. Sci. Nanosci. Nanotechnol. 2016, 7, 015002. [CrossRef]

79. Devi, T.B.; Ahmaruzzaman, M.; Begum, S. A rapid, facile and green synthesis of Ag@AgCl nanoparticles for the effective reduction of 2,4-dinitrophenyl hydrazine. New J. Chem. 2016, 40, 1497-1506. [CrossRef]

80. Durán, N.; Cuevas, R.; Cordi, L.; Rubilar, O.; Diez, M.C. Biogenic silver nanoparticles associated with silver chloride nanoparticles (Ag@AgCl) produced by laccase from Trametes versicolor. SpringerPlus 2014, 3, 645. [CrossRef] [PubMed]

81. Matsumura, Y.; Yoshikata, K.; Kunisaki, S.-I.; Tsuchido, T. Mode of bactericidal action of silver zeolite and its comparison with that of silver nitrate. Appl. Environ. Microbiol. 2003, 69, 4278-4281. [CrossRef] [PubMed]

82. Prabhu, S.; Poulose, E.K. Silver nanoparticles: Mechanism of antimicrobial action, synthesis, medical applications, and toxicity effects. Int. Nano Lett. 2012, 2, 32. [CrossRef]

83. Kim, S.-K. Handbook of Anticancer Drugs from Marine Origin; Springer: Basel, Switzerland, 2015.

84. Kim, S.-K. Springer Handbook of Marine Biotechnology; Springer: Berlin/Heidelberg, Germany, 2015.

85. Jeyaraj, M.; Rajesh, M.; Arun, R.; MubarakAli, D.; Sathishkumar, G.; Sivanandhan, G.; Dev, G.K.; Manickavasagam, M.; Premkumar, K.; Thajuddin, N. An investigation on the cytotoxicity and caspase-mediated apoptotic effect of biologically synthesized silver nanoparticles using podophyllum hexandrum on human cervical carcinoma cells. Colloids Surf. B 2013, 102, 708-717. [CrossRef] [PubMed] 
86. Chanthini, A.B.; Balasubramani, G.; Ramkumar, R.; Sowmiya, R.; Balakumaran, M.D.; Kalaichelvan, P.T.; Perumal, P. Structural characterization, antioxidant and in vitro cytotoxic properties of seagrass, Cymodocea serrulata (R.Br.) Asch. \& Magnus mediated silver nanoparticles. J. Photochem. Photobiol. B 2015, 153, 145-152. [PubMed]

87. Shen, Q.; Zhang, B.; Xu, R.; Wang, Y.; Ding, X.; Li, P. Antioxidant activity in vitro of the selenium-contained protein from the Se-enriched bifidobacterium animalis 01. Anaerobe 2010, 16, 380-386. [CrossRef] [PubMed]

(C) 2016 by the authors; licensee MDPI, Basel, Switzerland. This article is an open access article distributed under the terms and conditions of the Creative Commons Attribution (CC-BY) license (http:/ / creativecommons.org/licenses/by/4.0/). 